Western University Scholarship@Western

Centre for the Study of International Economic Centre for the Study of International Economic

Relations Working Papers

Relations

1980

\title{
Welfare Effects in Customs Unions
}

John McMillan

Ewan McCann

Follow this and additional works at: https://ir.lib.uwo.ca/economicscsier_wp

Part of the Economics Commons

Citation of this paper:

McMillan, John, Ewan McCann. "Welfare Effects in Customs Unions." Centre for the Study of International Economic Relations Working Papers, 8002. London, ON: Department of Economics, University of Western Ontario (1980). 
CENTRE FOR THE STUDY OF INTERNATIONAL ECONOMIC RELATIONS

WORKING PAPER NO. 8002

WELFARE EFFECTS IN CUSTOMS UNIONS

John McMillan

and

Ewen McCann

This paper contains preliminary findings from research still in progress and should not be quoted without prior approval of the author.

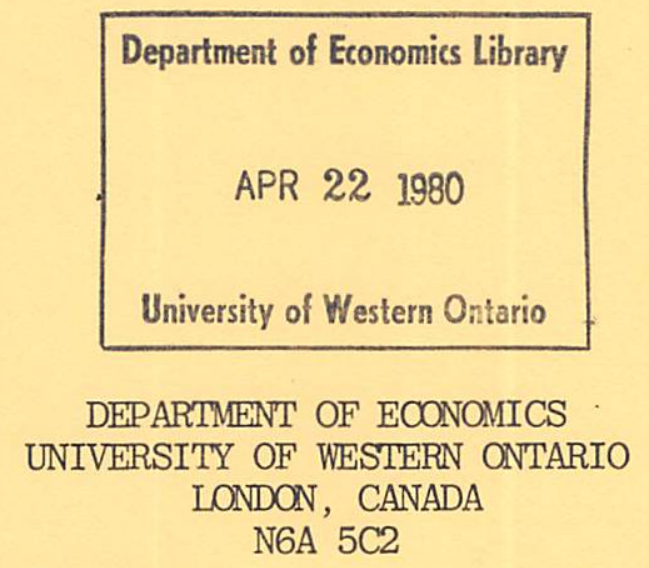




\title{
WELFARE EFFECTS IN CUSTOMS UNIONS
}

\author{
by \\ John McMillan \\ Department of Economics \\ University of Western Ontario \\ London, Ontario N6A 5C2 Canada \\ and \\ Ewen McCann \\ Department of Economics \\ University of Canterbury \\ Christchurch, 1 \\ New Zealand \\ October 1979
}

\section{ABSTRACT}

The three-country three-commodity model of customs unions is examined. A necessary and sufficient condition for a country to gain from the formation of a customs union is that the domestically-produced commodity and the commodity imported from the partner be net substitutes. Moreover, in such circumstances, the partner country is also better off as a result of the union. There should be free trade within the union if and only if the commodity imported from the partner and the commodity imported from the rest of the world are independent. The model is extended to the many-commodity, many-country case. 


\section{Introduction}

The literature on customs unions lacks a clear statement of the conditions which ensure a country can gain by joining a customs union. 1 This paper examines welfare effects in the three-country, three-commodity customs union model due to Meade (1955), Vanek (1965, Appendix) and Lipsey $(1970)^{2}$

2. The Meade-Vanek-Lipsey Mode1

The assumptions made are exactly those of Vanek (1965, pp. 189-191) and Lipsey (1970, pp. 32-33). There are three countries, A, B and C. A and B have linear production possibility frontiers such that A specializes in producing commodity $\mathrm{X}$ and $\mathrm{B}$ specializes in producing commodity $\mathrm{Y}$. Both $\mathrm{A}$ and $B$ import commodity $Z$ from country $C$. Countries $A$ and $B$ are small enough so that world prices $P_{x}^{W}, P_{y}^{W}, P_{z}^{W}$ are never affected by their actions; world prices are determined by country $C$. Before union, country A imposes a uniform ad valorem tariff $t_{z}>0$ on all imports. ${ }^{3} A$ and $B$ now form a union, lowering or possibly abolishing tariffs on trade with each other but retaining tariffs on trade with $C$ (the rest of the world). Thus A's tariff on commodity $Z$ remains at $t_{z}$ while its tariff on $Y$ is reduced to $t_{y^{\prime}}$. Post-union domestic prices in country $A$ are

$$
\begin{aligned}
& P_{x}^{a}=P_{x}^{w} \\
& P_{y}^{a}=\left(1+t_{y}\right) P_{y}^{w} \\
& P_{z}^{a}=\left(1+t_{z}\right) P_{z}^{w}
\end{aligned}
$$


It is assumed that there is no transhipment of commodity $Z$ within the union; this amounts to assuming $A$ and $B$ have a common tariff on commodity $Z$. Tariff proceeds are returned to consumers in lump-sum fashion.

Consumers' tastes are such that community indifference curves exist, represented by a quasi-concave utility function $U(X, Y, Z)$, the arguments of which are aggregate consumption in country $A$ of the three commodities. Country A's decision is to choose $t_{y}$ (which, by equation (2), is the same as choosing $\mathrm{P}_{\mathrm{y}}^{\mathrm{a}}$ ) so as to maximize its utility subject to the constraints (1) and (3) and subject to the balance of payments constraint

$$
P_{x}^{W} X+P_{y}^{W} Y+P_{z}^{W}=P_{x}^{W} S
$$

where $S$ is A's total output of its exportable commodity, which is constant because of the assumptions of linear production possibility frontier and specialization.

Note that the solution to this problem yields a not higher, and possibly much lower, level of utility than the solution to the problem of maximizing utility subject solely to the constraint (4) (because the latter problem has fewer constraints). The solution to the latter problem would have $t_{z}=t_{y}=0$; that is, free trade. The decision to keep $t_{z}$ strictly positive must be made on non-economic (or at least non-welfare-maximizing) grounds. The second-best problem to be investigated in the next section is, given country A's decision to retain the tariff on trade with country $\mathrm{C}$, when is it rational to form a customs union with country B? 
3. The Expenditure Function

Traditionally, welfare effects in customs unions problems have been described by means of trade creation and trade diversion. This leads to inconclusive results, because trade creation is not a sufficient condition for welfare gain and trade diversion is not sufficient for welfare loss. We avoid this approach, and instead describe welfare effects using the duality properties of the consumers' maximization problem.

The expenditure function $E\left(P_{x}^{a}, P_{y}^{a}, P_{z}^{a}, u\right)$ shows the minimum expenditure necessary at domestic prices to achieve a given level of utility $u$. E is, with respect to prices, non-decreasing, concave and continuous. The partial derivatives of $\mathrm{E}$ with respect to $\mathrm{P}_{\mathrm{x}}^{\mathrm{a}}, \mathrm{P}_{\mathrm{y}}^{\mathrm{a}}$ and $\mathrm{P}_{\mathrm{z}}^{\mathrm{a}}$ are the compensated (Hicksian) demand functions for $X, Y$ and $Z$ respectively. Thus the balance of payments constraint (4) can be rewritten

$$
P_{x}^{w} \frac{\partial E}{\partial P_{x}^{a}}+P_{y}^{w} \frac{\partial E}{\partial P_{y}^{a}}+P_{z}^{w} \frac{\partial E}{\partial P_{z}^{a}}=P_{x}^{w} S
$$

Differentiate (5) totally with respect to country A's control variable, $\mathrm{P}_{\mathrm{y}}^{\mathrm{a}}$.

$$
\begin{gathered}
P_{x}^{w} \frac{\partial^{2} E}{\partial P_{x}^{a} \partial P_{y}^{a}}+P_{x}^{w} \frac{\partial^{2} E}{\partial P_{x}^{a} \partial u} \frac{d u}{d P_{y}^{a}}+P_{y}^{w} \frac{\partial^{2} E}{\partial P_{y}^{a^{2}}}+P_{y}^{w} \frac{\partial^{2} E}{\partial P_{y}^{a} \partial u} \frac{d u}{d P_{y}^{a}} \\
+P_{z}^{w} \frac{\partial^{2} E}{\partial P_{z}^{a} \partial P_{y}^{a}}+P_{z}^{w} \frac{\partial^{2} E}{\partial P_{z}^{a} \partial u} \frac{d u}{d P_{y}^{a}}=0
\end{gathered}
$$

Demand functions are homogeneous of degree zero in all prices; thus, by Euler's theorem,

$$
P_{x}^{a} \frac{\partial^{2} E}{\partial P_{x}^{a} \partial P_{y}^{a}}+P_{y}^{a} \frac{\partial^{2} E}{\partial P_{y}^{a^{2}}}+P_{z}^{a} \frac{\partial^{2} E}{\partial P_{z}^{a} \partial P_{y}^{a}}=0
$$

Rearranging (7), and using (1), (2) and (3), 


$$
P_{z}^{w} \frac{\partial^{2} E}{\partial P_{z}^{a} \partial P_{y}^{a}}=-\frac{1}{\left(1+t_{z}\right)}\left(P_{x}^{w} \frac{\partial^{2} E}{\partial P_{x}^{a} \partial P_{y}^{a}}+\left(1+t_{y}\right) P_{y}^{w} \frac{\partial^{2} E}{\partial P_{y}^{a^{2}}}\right)
$$

Substituting (8) in (6), and rearranging

$$
\frac{d u}{d P_{y}^{a}}=-\frac{\left(t_{z} P_{x}^{w} \frac{\partial^{2} E}{\partial P_{x}^{a} \partial P_{y}^{a}}+\left(t_{z}-t_{y}\right) P_{y}^{w} \frac{\partial^{2} E}{\partial P_{y}^{2}}\right)}{\left(1+t_{z}\right)\left(P_{x}^{w} \frac{\partial^{2} E}{\partial P_{x}^{a} \partial u}+P_{y}^{w} \frac{\partial^{2} E}{\partial P_{y}^{a} \partial u}+P_{z}^{a} \frac{\partial^{2} E}{\partial P_{z}^{a} \partial u}\right)}
$$

Expression (9) allows us to evaluate the effects on country A's welfare of the customs union.

The terms in the second bracket of the denominator of (9) can be written as $\partial\left(P_{x}^{W} X+P_{y}^{W}+P_{z}^{W}\right) / \partial u$, which is the rate of increase with respect to $\mathbf{u}$ of the minimum expenditure at world prices to achieve the level of utility $u$; this must be strictly positive and so the denominator is always strictly positive.

Consider now the numerator of expression (9). The term $\partial^{2} E / \partial P_{y}^{a}$ is the derivative with respect to $\mathrm{P}_{\mathrm{y}}^{\mathrm{a}}$ of the compensated demand for good $\mathrm{Y}$. Since the compensated demand curve is downward sloping, this term is negative. The term $\partial^{2} \mathrm{E} / \partial \mathrm{P}_{\mathrm{x}}^{\mathrm{a}} \partial \mathrm{P}_{\mathrm{y}}^{\mathrm{a}}$ is the derivative with respect to $\mathrm{P}_{\mathrm{y}}^{\mathrm{a}}$ of the compensated demand for good $X$; it is positive, zero or negative as commodity $X$ is respectively a net (Hicksian) substitute, independent, or a net complement for commodity $Y$. Thus whether or not the customs union is beneficial is determined by the Hicksian substitution relations between the commodities. ${ }^{4}$

\section{Welfare Effects}

The question posed by Meade (1955) was when is it that a customs union involving only small tariff changes is beneficial? Before union country $A$ has the same tariff rate on both $Y$ and $Z$. Putting $t_{y}=t_{z}$ in (9),

$$
\frac{d u}{d P_{y}^{a}} \lesseqgtr 0 \text { as } \frac{\partial^{2} E}{\partial P_{x}^{a} \partial P_{y}^{a}} \gtreqless 0
$$


That is, a small reduction in the tariff on good $Y$ from the pre-union situation increases country $A$ 's welfare if and only if commodity $X$ is a net substitute for commodity $\mathrm{Y}$.

Realistically, customs unions involve significant, not marginal, reductions in tariffs. Condition (9) can be solved for what Lipsey (1970, p. 36) called the "second-best optimum tariff" on commodity $Y$ given the fixed tariff $t_{z}$ on commodity $\mathrm{Z}$. Putting $\mathrm{du} / \mathrm{dP}_{\mathrm{y}}^{\mathrm{a}}=0$ and rearranging,

$$
t_{z}-t_{y}=-\frac{t_{z} p_{x}^{w} \partial^{2} E / \partial P_{x}^{a} \partial P_{y}^{a}}{P_{y}^{w} \partial^{2} E / \partial P_{y}^{a^{2}}}
$$

Thus

$$
t_{z} \gtreqless t_{y} \text { as } \frac{\partial^{2} E}{\partial P_{x}^{a} \partial P_{y}^{a}} \gtreqless 0
$$

The second-best optimum tariff on $Y$. is less than the fixed tariff on $Z$ if and only if commodity $X$ is a net substitute for commodity $Y .^{5}$ The country gains from the lowering of tariffs consequent on the formation of the customs union if and only if the domestically-produced commodity is a net substitute for the commodity imported from the partner country. Note that this result is independent of the nature of commodity $Z$ and is independent of such variables as the size of the tariff with the rest of the world and the relative volume of trade with the partner and with the rest of the world.

\section{Partial Versus Complete Union}

Equation (11) can be solved for the ideal tariff on trade within the union. Usually this will yield a non-zero value of $t_{y}$. Given the distortion of the fixed tariff on $Z$, free trade within the union will usually not maximize welfare; a partial customs union is usually preferable to a complete customs union. (This point was made by Meade, 1955, p. 110, and Lipsey, 1970, p. 38.) 6 A necessary and sufficient condition can be given, however, for free trade within 
the union to be optimal. Solving equation (11) for $t_{y}$ and using (1) and (2),

$$
t_{y}=\frac{t_{z}\left(P_{x}^{a} \frac{\partial^{2} E}{\partial P_{x}^{a} \partial P_{y}^{a}}+P_{y}^{a} \frac{\partial^{2} E}{\partial P_{y}^{a^{2}}}\right)}{P_{y}^{a} \frac{\partial^{2} E}{\partial P_{y}^{a^{2}}-t_{z} P_{x}^{a} \frac{\partial^{2} E}{\partial P_{x}^{a} \partial P_{y}^{a}}}}
$$

If the customs union is beneficial, then $\partial^{2} E / \partial P_{x}^{a} \partial P_{y}^{a}>0$. Then, since $\partial^{2} E / \partial P_{y}^{a^{2}}<0$, the denominator cannot be zero. The numerator, by (7), is equal to $-t_{z} P_{z}^{a} \partial^{2} E / \partial P_{z}^{a} \partial P_{y}^{a}$. Thus $t_{y}=0$ if and only if $\partial^{2} E / \partial P_{z}^{a} \partial P_{y}^{a}=0$. Free trade within the union is optimal if and only if the commodity imported from the partner country is neither a net complement nor a net substitute, for the commodity imported from the rest of the world.

Note also that (13) implies that if, and only if, commodity $Z$ is a net complement of commodity $Y, t_{y}$ is negative; that is, country A should subsidize intra-union trade. If, and only if, $X$ is a net substitute for $Z$ and $X$ is a net substitute for $Y$, country A's tariff on trade with country $B$ should be greater than zero but less than the tariff on trade with the rest of the world.

6. Customs Union Versus Unilateral Tariff Reduction

So far the problem has been considered only from the point of view of country A. Country B's actions have not entered the analysis. What has been described above as the formation of a customs union could be interpreted instead as a unilateral tariff reduction by country $A .^{7}$ The analysis, however, is completely symmetrical: Elementary calculus says $\partial^{2} E / \partial P_{x}^{a} \partial P_{y}^{a}=\partial^{2} E / \partial P_{y}^{a} \partial P_{x}^{a}$; that is, $X$ is a net substitute for $Y$ if and only if $Y$ is a net substitute for $\mathrm{X}$. Assume the utility functions in country $\mathrm{A}$ and country $\mathrm{B}$ are identical (or at least similar enough to preserve the property of two goods being net substitutes). 
Then the condition which ensures that country A gains from lowering its tariff on commodity $Y$, namely that $X$ is a net substitute for $Y$, is identical to the condition which ensures that country B gains from lowering its tariff on commodity $X$, namely that $Y$ is a net substitute for $X$. Country $A$ gains from the formation of a customs union with country $B$ if and only if $B$ also gains from it.

This result contrasts with results on welfare effects in the two-commodity customs union model. In the only pattern of trade possible in the two-good model, one country, say $B$, is isolated from the rest of the world and trades only with its partner, A. Then, as Kemp (1969, pp. 31,72) showed, the customs union benefits only country B and makes country A worse off (though B's gains may be large enough that $B$ has the potential to compensate $A$ for its losses and itself remain better off). This asymmetry of gains reflects the asymmetry of the trade pattern in the two-good model (compare with footnote 2). 
7. The Many-Commodity, Many-Country Case

Continue to assume there are only three countries. The model can be extended to cover the case of many commodities by interpreting the three countries' commodities $\mathrm{X}, \mathrm{Y}$ and $\mathrm{Z}$ as composite commodities. (This is valid as Iong as there is no change in the relative prices of the basic commodities which make up the composite commodities; that means that if, for example, country A reduces its tariffs on imports from country B, the percentage reduction mast be the same for all imports from country B.) Thus commodity $\mathrm{X}$, for example, is composed of $\mathrm{n}$ basic commodities $\mathrm{X}_{1}, \ldots, \mathrm{X}_{\mathrm{n}}$ (these basic commodities being defined by country of origin as well as physical characteristics), with world prices $\mathrm{P}_{\mathrm{x}_{1}}^{\mathrm{W}}, \ldots, \mathrm{P}_{\mathrm{x}_{\mathrm{n}}}^{\mathrm{W}}$, respectively, such that

$$
\mathrm{X}=\mathrm{x}_{1}+\left(\mathrm{P}_{\mathrm{x}_{2}}^{\mathrm{W}} / \mathrm{P}_{\mathrm{x}_{1}}^{\mathrm{W}}\right) \mathrm{x}_{2}+\ldots+\left(\mathrm{P}_{\mathrm{x}_{\mathrm{n}}}^{\mathrm{W}} / \mathrm{P}_{\mathrm{x}_{1}}^{\mathrm{W}}\right) \mathrm{x}_{\mathrm{n}}
$$

and the price of $\mathrm{X}, \mathrm{P}_{\mathrm{X}}^{\mathrm{W}}$, is $\mathrm{P}_{\mathrm{x}_{1}}^{\mathrm{W}}$. The $\mathrm{X}^{\prime} \mathrm{s}$ represent compensated demands. Differentiating partially with respect to the domestic price of composite commodity $Y$,

$$
\frac{\partial \mathrm{x}}{\partial \mathrm{P}_{\mathrm{y}}^{\mathrm{a}}}=\frac{\partial \mathrm{x}_{1}}{\partial \mathrm{P}_{\mathrm{y}}^{\mathrm{a}}}+\frac{\mathrm{P}_{\mathrm{x}_{2}}^{\mathrm{w}}}{\mathrm{P}_{\mathrm{x}_{1}}^{\mathrm{w}}} \frac{\partial \mathrm{x}_{2}}{\partial \mathrm{P}_{\mathrm{y}}^{\mathrm{a}}}+\ldots+\frac{\mathrm{P}_{\mathrm{x}_{\mathrm{n}}}^{\mathrm{w}}}{\mathrm{P}_{\mathrm{x}_{1}}^{\mathrm{w}}} \frac{\partial \mathrm{x}_{\mathrm{n}}}{\partial \mathrm{P}_{\mathrm{y}}^{\mathrm{a}}}
$$

The term $\partial \mathrm{x} / \partial \mathrm{P}_{\mathrm{y}}^{\mathrm{a}}$ is the aggregate substitution term, formerly denoted $\partial^{2} E / \partial P_{x}^{a} \partial P_{y}^{a}$, the sign of which determines whether or not the customs union is beneficial. From (15), this term is the price-weighted sum of individual substitution terms.

Now consider a world of m small countries, each specialized in the production of a particular (composite) commodity. Country $C$ in the above analysis can be thought of as being made up of m-2 such countries and 
commodity $\mathrm{Z}$ is the aggregate of their output. Countries $\mathrm{A}$ and $\mathrm{B}$ are the remaining two countries. The composite commodities satisfy the standard assumptions of consumer theory. A well-known result from consumer theory says that every commodity has at least one net substitute. Thus for each country A there is another country B with which A can advantageously form a customs union. More can be said than that, however. A theorem due to Mosenson and Dror (1972) says that any good is connected by a chain of net substitutes to any other good. Start with each country imposing a uniform tariff on all its imports. Suppose $A^{\prime} s$ and $B^{\prime} s$ commodities are net substitutes and each lowers its tariff on the other's commodity. Among the countries making up the rest of the world, there will be another country $D$ such that $D^{\prime} s$ commodity is a net substitute for $B^{\prime} s$. Put $A$ in with the rest of the world and consider the pair $B$ and $D$. $B^{\prime}$ 's tariff on the composite good from the rest of the world is lower than its tariff on D's good (since B's tariff on the rest of the world is a weighted average of the tariff on $A$ and that on all the other countries except $D$, and the tariff on $A$ has been lowered). D's tariffs are still uniform. Thus condition (12) indicates that B and D can both gain by mutually lowering tariffs. Now consider another net substitute pairing $D$ and $E$. A similar process occurs. Incentives exist for a sequence of bilateral agreements mutually to reduce tariffs, until every country has lowered tariffs on trade with at least one other country. Depending on the particular pattern of substitution relations, this process may or may not end up with free trade. Kemp and Wan (1976) obtained, by a different argument, a related result, namely that there is an incentive for customs unions to enlarge until the world is one large customs union, that is free trade prevails. Their result, however, unlike this one, required the transfer of lump-sum compensatory payments between union members. 
8. Summary

The three-commodity, three-country model of customs unions due to Lipsey, Meade and Vanek was examined. 9 A country gains from the lowering of tariffs following the formation of a customs union if and only if the domestically-produced commodity and the commodity imported from the partner country are net substitutes (regardless of the nature of the commodity imported from the rest of the world). Moreover, in such circumstances, the partner country is also better off as a result of the union. There should be free trade within the customs union if and only if the commodity imported from the partner is neither a net substitute nor a net complement for the commodity imported from the rest of the world. If, and only if, the two commodities imported by a member country are net complements, the country should subsidize intraunion trade. The model extends to the case of many commodities, via the composite commodity theorem. In a many country world there will be incentives for countries to make a sequence of bilateral agreements mutually to reduce tariffs, until each country has reduced its tariff on trade with at least one other country.

Final1y, note that this model ignores other ways in which a customs union could create welfare gains for its members, such as by explaiting economies of scale or terms of trade effects, or by countering domestic distortions: 10 
Footnotes

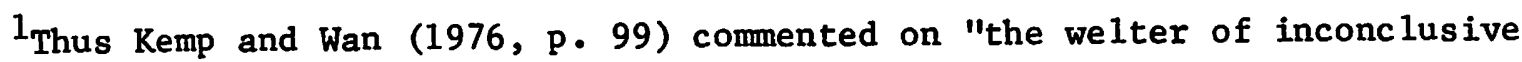
debate concerning the implications of customs unions."

2 The three-commodity model is to be distinguished from the two-commodity model (Krauss, 1972), to which much of the formal work on customs unions has been confined. As Lipsey (1960) argued, this framework is inadequate for examining welfare effects.

${ }^{3}$ Corden (1976) dealt with the case in which, in a three-commodity model, tariffs are initially non-uniform. Corden, however, assumed the domesticallyproduced commodity is not consumed domestically.

This is consistent with a result of Lloyd (1974) who showed that the Hicksian substitution relations are enough to characterize second-best policies for an open economy- Dixit (1975) used the expenditure function to derive results on second-best policies.

${ }^{5}$ This result is consistent with, but generalizes and simplifies, the taxonomy of special cases 1 isted by Lipsey (1970, Pp. 36-38). Note that Lipsey (1970, p. 156, n. 7) pointed out that his results, as they stand, cannot be expressed in terms of complementarity and substitutability.

${ }^{6}$ As Wonnacott and Wonnacott (1979) pointed out, this goes against GATT rules, which prohibit bilateral agreements partially to reduce tariffs but allow agreements to reduce tariffs to zero.

${ }^{7}$ This comment applies to most of the customs unions literature. On the benefits of a customs union contrasted with those of a unilateral tariff reduction, see Wonnacott and Wonnacott (1979).

${ }^{8}$ On the appropriate level of aggregation with which to model customs unions, see Collier (1979). 
${ }^{9}$ In a recent paper, Berglas (1979) examined a three-good customs union model. His results are different from those of this paper, however, because he assumed a different pattern of trade (retaining the asymmetry of the two-good model) and he assumed that all goods are gross substitutes.

${ }^{10}$ On the first question, see Corden (1972) and Manning and McMillan (1979); on the second, Melvin (1969) and Riezman (1979); and on the third, Whalley (1979). 


\section{$\underline{\text { References }}$}

Berglas, E. (1979). "Preferential Trading Theory: The n Commodity Case," Journal of Political Economy, Vo1. 87 (April), pp. 315-332.

Collier, P. (1979). "The Welfare Effects of Customs Union: An Anatomy," Economic Journal, Vo1. 89 (March), pp. 84-95.

Corden, W. M. (1972). "Economies of Scale and Customs Union Theory," Journal of Political Economy, Vo1. 80 (May/June), pp. 465-475.

Corden, W. M. (1976). "Customs Union Theory and the Nonuniformity of Tariffs," Journal of International Economics, Vol. 6 (February), pp. 99-106.

Dixit, A. (1975). "Welfare Effects of Tax and Price Changes," Journal of Public Economics, Vo1. 4 (February), Pp. 103-123.

Kemp, M. C. (1969). A Contribution to the General Equilibrium Theory of Preferential Trading, Amsterdam: North-Holland.

Kemp, M.C. and Wan, H. Y. (1976). "An Elementary Proposition Concerning the Formation of Customs Unions," Journal of International Economics, Vol. 6 (February), pp. 95-98.

Krauss, M. B. (1972). "Recent Developments in Customs Union Theory: An Interpretive Survey," Journal of Economic Literature, Vol. 10 (June), pp. $413-436$.

Lipsey, R. G. (1960). "The Theory of Customs Unions: A General Survey," Economic Journal Vo1. 70 (September), pp. 496-513.

Lipsey; R. G. (1970). The Theory of Customs Unions: A General Equilibrium Analysis, London: Weidenfeld and Nicolson.

Lloyd, P. J. (1974). "A More General Theory of. Price Distortions in Open Economies," Journal of International Economics, Vo1. 40 (November), pp. $365-386$

Manning, R. and McMillan, J. (1979). "Public Intermediate Goods, Production Possibilities and International Trade," Canadian Journal of Economics, Vol. 12 (May), Pp. 243-257. 
Meade, J. E. (1955). The Theory of Customs Unions, Amsterdam: North-Holland. Melvin, J. R. (1969). "Comments on the Theory of Customs Unions," Manchester School, Vol. 36 (June), pp. 161-168.

Mosenson, R. and Dror, E. (1972). "A Solution to the Qualitative Substitution Problem in Demand Theory," Review of Economic Studies, Vo1. 39 (October), pp. $433-441$.

Riezman, R. (1979). "A $3 \times 3$ Model of Customs Unions," Journal of International Economics, Vol. 9 (August), pp. 341-354.

Vanek, J. (1965). General Equilibrium of International Discrimination: The Case of Customs Unions, Cambridge, Mass.: Harvard University Press.

Whalley, J. (1979) \%" "Uniform Domestic Tax Rates, Trade Distortions, and Economic Integration," Journal of Public Economics, Vol. 11 (Apri1), pp。213-221:

Wonnacott, P. and Wonnacott, R. (1979). "Is Unilateral Tariff Reduction Preferable to a Customs Union? The Curious Case of Missing Foreign Tariffs: Or, Beware of the Large Country Assumption," Working Paper 79-24, Department of Economics, University of Maryland. 
CENTRE FOR THE STUDY OF INTERNATIONAL ECONOMIC RETATIONS

$$
\begin{gathered}
\text { University of Western Ontario } \\
\text { Working Papers }
\end{gathered}
$$

8001. Robson, Arthur J. OPEC VERSUS THE WEST: A ROBUST DUOPOLY SITUATION

8002. McMillan, John and Ewen McCann. WELFARE EFFECIS IN CUSTOMS UNIONS

8003. Leith, J. Clark. MONEY, THE BALANCE OF PAYMENTS, AND GOVEPNMENT DEBT IN A SMALL OPEN LDC: HAITI

8004. Mansur, Ashan and John Whalley. A DEOOMPOSITION ALGORITHM FOR GENERAL EQUILIBRIUM COMPUTATION WITH APPLICATION. TO INTERNATIONAL TRADE MODELS

8005. Schmid, Michael. OIL, EMPLOKMENT AND THE PRICE LEVEL: A MONETARY APPBOACH TO THE MACROECONOMICS OF IMPORTED INIERMEDIATE COODS UNDER FIXED AND FLEXIBLE RATES

8006. Markusen, James R. THE DISTRIBUTION OF GAINS FROM BILATERAL TARIFF REDUCTION 8007. Markusen, James R. TRADE AND THE GAINS FROM TRADE WITH IMPERFECT COMPETITION 8008. Markusen, James R. and James R. Melvin. TRADE, FACTOR PRICES, AND THE GAINS FROM TRADE WITH INCREASING BETURNS TO SCALE 